\title{
SEPAKBOLA: KAPASITAS VITAL PARU DAN TINGKAT KEBUGARAN JASMANI
}

\author{
Rusmanto*1, Rola Angga Lardika $^{2}$, Novri Gazali ${ }^{3}$ \\ Universitas Riau, Indonesia ${ }^{1,2}$, Universitas Islam Riau, Indonesia ${ }^{3}$ \\ Email: rusmanto@lecturer.unri.ac.id ${ }^{* 1}$, rolaanggalardika@lecturer.unri.ac.id ${ }^{2}$, \\ novri.gazali@edu.uir.ac.id ${ }^{3}$
}

\author{
Received: 07 April 2020; Accepted 18 May 2020; Published 06 June 2020
}

Ed 2020; 5(1): 30-39

\begin{abstract}
ABSTRAK
Kapasitas vital paru adalah status kondisi fisiologis yang terkait dengan kemampuan mengolah pernapasan bersamaan dengan peningkatan kebugaran fisik, maka kapasitas vital paru adalah proses yang melibatkan mekanisme jantung dan pembuluh darah serta darah yang bertujuan untuk memberikan $\mathrm{O}_{2} \mathrm{ke}$ sel-sel dalam tubuh dan mengangkut $\mathrm{CO}_{2}$ ke luar tubuh. Penelitian ini bertujuan untuk mengetahui korelasi kapasitas vital paru dengan tingkat kebugaran jasmani atlet Sepakbola Pendor Universitas Riau. Data yang dikumpulkan adalah data tes kapasitas vital paru dan kebugaran jasmani dengan jumlah sampel sebanyak 20 atlet. Analisis data yang digunakan untuk mengolah data adalah korelasi Product Moment. Untuk menetukan signifikansi data gunakan rumus distribusi t. Hasil yang diperoleh dari kapasitas vital paru memiliki hubungan yang signifikan dengan tingkat kebugaran fisik, dengan dengan hasil yang diperoleh oleh $r$ count $(0622)>r$ table $(\alpha=0,05)=0,456$. Sedangkan uji distribusi t dipeoleh hasil $t$ count $(3,369)>t$ table $(1,734)$, maka $\mathrm{H}_{0}$ ditolak dan $\mathrm{H}_{\mathrm{a}}$ diterima. Dapat disimpulkan bahwa terdapat hubungan yang signifikan antara variabel bebas dengan variabel terikat yaitu korelasi antara kapasitas vital paru (x) dengan tingkat kebugaran Jasmani (y).
\end{abstract}

Kata Kunci: Kapasitas Vital Paru; Kebugaran Jasmani; Sepakbola

\section{FOOTBALL: LUNG VITAL CAPACITY AND PHYSICAL FITNESS LEVEL}

\begin{abstract}
Lung vital capacity is the status of physiological conditions associated with the ability to treat respiration together with the increasing of physical fitness, so lung vital capacity is a process involving the mechanism of the heart and blood vessels and blood which aims to provide $\mathrm{O}_{2}$ to cells in the body and transport $\mathrm{CO}_{2}$ out of body. The purpose of this study is to determine the correlation between lung vital capacity and the physical fitness level of Pendor Football Athletes from Universitas Riau. The collecting of data in this study is data from lung vital capacity tests and physical fitness with a sample of 20 athletes. Analysis of the data that used to process data is Product Moment correlation. For determining the significance of data, it uses formulation of $t$ distribution. The results that obtained from lung vital capacity have a significant correlation with the level of physical fitness, this is indicated by the results obtained by $r$ count $(0622)>r$ table $(\alpha=0.05)=0.456$. Meanwhile, $t$ distribution test is obtained the result of $t$ count $(3,369)>t$ table $(1,734)$. So $H_{0}$ is refused and $H_{a}$ is accepted. Thus it can be concluded that there is a significant correlation between the lung vital capacity $(x)$ and the level of physical fitness (y).
\end{abstract}

Keywords: Lung Vital Capacity;Physical Fitness; Football

Copyright $@$ C 2020, Journal Sport Area

DOI: https://doi.org/10.25299/sportarea.2020.vol5(1).4791

How To Cite: Rusmanto, Lardika, R. A., \& Gazali, N. (2020). Sepakbola: Kapasitas Vital Paru dan Tingkat Kebugaran Jasmani. Journal Sport Area, 5(1), 30-39. 


\section{PENDAHULUAN}

Kebugaran jasmani dapat menentukan derajat hidup sehat statis dan dinamis seseorang. Saat ini kebugaran jasmani belum terlalu diperhatikan atlet, mengingat atlet yang terlalu fokus terhadap latihan sehingga mengesampingkan pentingnya kebugaran jasmani yang kuat. Arti penting kebugaran jasmani bagi seseorang individu antara lain adalah meningkatkan fungsi organ tubuh, sosial emosional diri, sportivitas yang tinggi, dan semangat kompetisi (Chu, Chen, Pontifex, \& Sun, 2016). Melalui aktivitas fisik yang teratur akan memperoleh gerakan dan fungsi organ tubuh yang memadai untuk pengembangan kemampuan fisik dan sendi yang lebih baik (Sujarwo, Tangkudung, \& Hanif, 2018). Bahkan beberapa penelitian yang menyatakan bahwa kebugaran jasmani mempunyai korelasi positif dengan prestasi akademik (Chu et al., 2016; Morita, Nakajima, Okita, Ishihara, Sagawa, \& Yamatsu, 2016; Raine, Biggan, Baym, Saliba, Cohen, \& Hillman, 2017). Rancangan tugas gerak tidak cukup hanya mengandung unsur-unsur masalah gerak yang harus dipecahkan atlet, tetapi harus sesuai dengan fungsi, kaedah gerak, dan tujuan yang ingin dicapai (Lardika \& Tulyakul 2020). Selain itu, dengan meningkatnya kebugaran juga akan meningkatkan prestasi olahraga termasuk sepakbola. Kemampuan fisik para pemain memberikan efek yang nyata pada taktik tim karena permainan sepakbola menuntut pengulangan tenaga maksimum dan pada keterampilan para pemain (Tahara, Moji, Tsunawake, Fukuda, Nakayama, Nakagaichi, ... Aoyagi, 2006). Selain faktor teknis dasar yang harus dikuasai, faktor kondisi fisik juga sangat dibutuhkan dalam permainan sepakbola (Zainur \& Lardika, 2019). Kemampuan teknis dan taktis adalah komponen penting dari kinerja sepakbola (BenOunis, BenAbderrahman, Chamari, Ajmol, BenBrahim, Hammouda, ... Zouhal, 2013). Sebuah badan penelitian yang sedang berkembang telah menyoroti manfaat kesehatan dari olahraga sepakbola (Hammami, Randers, Kasmi, Razgallah, Tabka, Chamari, \& Bouhlel, 2018).

Ada kebutuhan untuk mengkarakterisasi profil fisik dan kebugaran yang lebih tinggi dalam permainan sepakbola (Gastin, Tangalos, Torres, \& Robertson, 2017). High Intensity Interval Training (HIIT) telah dikenal sebagai jenis latihan waktu yang ekonomis untuk memasarkan keunggulan kesehatan dan meningkatkan kebugaran (Cvetković, Stojanović, Stojiljković, Nikolić, Scanlan, \& Milanović, 2018). Studi menunjukkan bahwa olahraga tim yang berhubungan dengan sepakbola mungkin memiliki nilai lebih (profil fisik dan kebugaran) dari olahraga individu (Bennike, Wikman, \& Ottesen, 2014).

Kebugaran jasmani juga sangat erat hubungannya dengan volume dan kualitas udara yang kita hirup, ini dijelaskan dalam beberapa penelitian yang membahas pengaruh minat fisik pada hasil pemeriksaan fungsi paru dan menyelidiki hubungan antara komposisi kerangka dan parameter pernapasan pada atlet (Durmic, Lazovic, Djelic, Lazic, Zikic, Zugic, Decleva, \& Mazic, 2015). Banyak sedikitnya volume udara tergantung dari baik buruknya kapasitas paru-paru kita dan juga dipengaruhi oleh baik buruknya kualitas udara yang kita hirup. Kemampuan penggunaan oksigen oleh tubuh mempunyai kemampuan terbatas dalam pengambilan oksigen. Pada kenyataannya bahwa ada juga kelangkaan penelitian mengatasi langkah-langkah spirometrik unik untuk atlet, yang dapat menyebabkan kesalahan klasifikasi atau kesalahan diagnosis disfungsi pernapasan positif (Durmic et al., 2015).

Smith, Berg, Berdel, Bauer, Hoffmann, Koletzko, ... Schulz, (2016) memperkirakan hubungan antara indeks spirometrik dan minat fisik akselerometrik pada remaja yang 
sehat paru-paru. Spirometri adalah karakteristik paru-paru emas yang diketahui yang mengukur bagaimana seseorang menghirup atau menghembuskan volume udara sebagai fitur waktu (Durmic et al., 2015). Peningkatan pernafasan merupakan respon yang diharapkan dan cocok untuk hobi fisik yang mencerminkan dorongan peningkatan ventilasi dan diamanatkan untuk terus berhasil melakukan hobi seperti itu (Price, Hull, Ansley, Thomas, \& Eyles, 2016). Partisipasi dalam pelatihan multi-aspek latihan mungkin kuat dalam merangsang secara bersamaan semua 3 bidang kesehatan utama, dengan demikian menyediakan kebugaran spektrum luas dan manfaat kesehatan (Milanović et al., 2019). Sistem kardiovaskular pada pelatihan jenis permainan khusus dan prosedur reversibilitas setelah berhentinya pelatihan pada orang dewasa adalah fakta yang nyata (Durmic, Popovic, Svenda, Djelic, Zugic, Gavrilovic, ... Leischik, 2017).

Kondisi terbatas pada dinding dada muncul pada penyakit yang termasuk obesitas atau skoliosis, tetapi juga dengan situasi pekerjaan bersama dengan olahraga (Coast, Baronas, Morris, \& Willeford, 2005). Pernapasan Sectional yang melibatkan kesadaran individu membantu memperbaiki pola pernapasan yang tidak efisien dan pertumbuhan Kapasitas Vital paru-paru (Hakked, Balakrishnan, \& Krishnamurthy, 2017).

Pada saat seseorang berolahraga, produksi karbondioksida akan bertambah dan kebutuhan $\mathrm{O}_{2}$ dalam sel-sel sangat tinggi. Pembuangan $\mathrm{CO}_{2}$ yang meningkat dilakukan oleh sistem pernapasan. Sehingga pada olahraga yang intensif, frekuensi pernapasan akan bertambah guna menghasilkan ventilasi paru yang besar. Adapun kegunaan hasil kenaikan ventilasi paru ini akan menambah pengiriman $\mathrm{O}_{2}$ dan mempercepat pembuangan $\mathrm{CO}_{2}$. Orang yang terlatih cenderung mendalamnya pernapasan tetapi tidak begitu dengan frekuensi pernafasannya. Orang yang tidak terlatih frekuensi pernapasannya semakin meningkat (Hakked et al., 2017). Setiap penarikan napas selalu ada udara yang tidak sampai pada alveoli, udara tersebut hanya ada pada ruang mati. Semakin banyak frekuensi pernapasan maka semakin banyak pula udara yang tidak ikut menyegarkan alveoli. Kesimpulannya semakin tinggi frekuensi pernapasan artinya itu kurang efisien.

Penelitian ini memungkinkan praktisi bidang olahraga untuk memperhatikan kualitas latihan yang sesuai untuk meningkatkan kualitas vital paru. Latihan-latihan yang diberikan pelatih saat ini adalah kegiatan yang harus membuat tubuh seseorang bergerak tanpa melihat tujuan dari aktivitas latihannya. Jika kemampuan otot dan organ pernafasan baik maka akan mampu memenuhi kebutuhan oksigen $\left(\mathrm{O}_{2}\right)$ dalam tubuh untuk melakukan aktifitas yang cukup lama. Artinya penelitian ini memiliki fokus yang berbeda dengan penelitian-penelitian sebelumnya. Jika penelitian lain, kapasistas vital paru dipengaruhi oleh faktor eksternal seperti kegiatan merokok serta akibatnya terhadap kapasitas vital paru dan kebugaran jasmani, maka penelitian ini lebih kepada bagaimana memilih kegiatan yang bermakna untuk meningkatkan kapasitas vital paru sehingga secara langsung seseorang akan memiliki tingkat kebugaran fisik yang baik pula.

\section{METODE PENELITIAN}

Rancangan penelitian ini merupakan penelitian korelasional, penelitian korelasional dipilih karena sinkron menggunakan arah penelitian penulis yaitu melihat hubungan antara variabel bebas dan variabel terikat. Adapun variabel bebas pada penelitian ini merupakan kapasitas vital paru dan variabel terikat merupakan kebugaran jasmani. Populasi dalam penelitian ini adalah atlet Sepakbola Pendor Universitas Riau yang 
berjumlah 20 orang. Teknik penarikan sampel menggunakan total sampling yaitu teknik penentuan sampel dengan semua anggota populasi digunakan sebagai sampel apabila jumlah populasi kurang dari 30. Pelaksanaan tes menggunakan jenis tes lari 12 menit untuk mengukur kebugaran jasmani (Mackenzie, 2005), spirometric measures untuk mengukur kapasitas vital paru (Moore, 2012). Pengolahan data dilakukan dengan teknik korelasi product moment:

$$
r_{X y}=\frac{N\left(\sum X Y\right)-\left(\sum X\right)\left(\sum Y\right)}{\sqrt{\left\{\left(N \sum X^{2}\right)-\left(\sum x\right)^{2}\right\}}\left\{\left(N \sum Y^{2}\right)-\left(\sum Y\right)^{2}\right\}}
$$

Selanjutnya untuk menetukan signifikansi dilakukan dengan menggunakan distribusi t yaitu:

$$
t=\frac{r x y \sqrt{n-2}}{\sqrt{1-r x y^{2}}}
$$

\section{HASIL DAN PEMBAHASAN}

Kapasitas Vital Paru

Untuk lebih jelasnya distribusi frekuensi hasil pengukuran kapasitas paru dapat kita lihat pada tabel 1 .

Tabel 1. Distribusi Frekuensi Kapasitas Vital Paru

\begin{tabular}{cccc}
\hline No & Kelas Interval & Frekuensi Absolute (FA) & Frekuensi Relative (FR) \\
\hline 1 & $1280-1408$ & 1 & 5 \\
\hline 2 & $1409-1537$ & 3 & 15 \\
\hline 3 & $1538-1666$ & 1 & 5 \\
\hline 4 & $1667-1795$ & 8 & 40 \\
\hline 5 & $1796-1924$ & 7 & 35 \\
\hline & Jumlah & $\mathbf{2 0}$ & $\mathbf{1 0 0 \%}$ \\
\hline
\end{tabular}

Berdasarkan tabel 1, hasil pengukuran kapasitas vital paru tehadap 20 orang sampel diperoleh 1 orang (5\%) memiliki kapasitas vital paru 1280-1408, sedangkan 3 orang (15\%) memiliki kapasitas vital paru 1409-1537, selanjutnya 1 orang (5\%) memiliki kapasitas vital paru 1538-1666, kemudian 8 orang (40\%) memiliki kapasitas vital paru 1667-1795, dan sisanya 7 orang (35\%) memiliki kapasitas vital paru 1796-1924. Agar lebih jelasnya distribusi frekuensi kapasitas vital paru $(\mathrm{x})$ dapat dilihat pada gambar histogram 1.

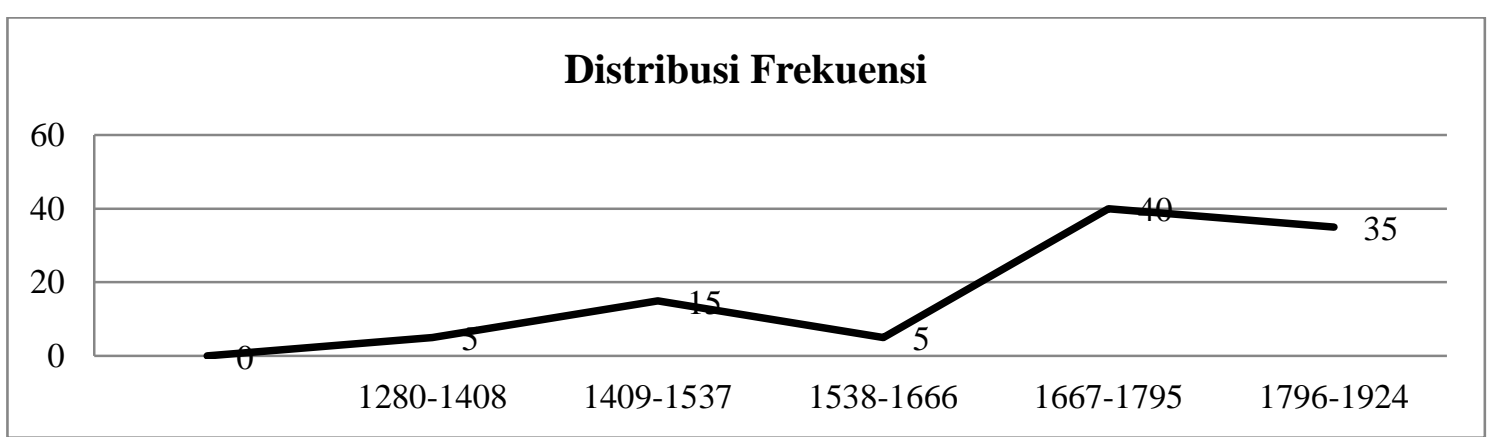

Gambar 1. Histogram Kapasitas Vital Paru 


\section{Tingkat Kebugaran Jasmani}

Berikut distribusi hasil pengukuran tingkat kebugaran jasmani, dapat dilihat pada tabel 2:

Tabel 2. Distribusi Frekuensi Tingkat Kebugaran Jasmani

\begin{tabular}{cccc}
\hline No & Kelas Interval & Frekuensi Absolute (FA) & Frekuensi Relative (FR) \\
\hline 1 & $1100-1480$ & 4 & 20 \\
\hline 2 & $1481-1861$ & 1 & 5 \\
\hline 3 & $1862-2242$ & 9 & 45 \\
\hline 4 & $2243-2623$ & 5 & 25 \\
\hline 5 & $2624-3004$ & 1 & 5 \\
\hline & Jumlah & $\mathbf{2 0}$ & $\mathbf{1 0 0 \%}$ \\
\hline
\end{tabular}

Berdasarkan tabel 2, hasil pengukuran tingkat kebugaran jasmani terhadap 20 orang sampel diperoleh 4 orang (20\%) memiliki tingkat kebugaran jasmani 1100-1480, sedangkan 1 orang (5\%) memiliki tingkat kebugaran jasmani 1481-1861, selanjutnya 9 orang (45\%) memiliki tingkat kebugaran jasmani 1862-2242, kemudian5 orang (25\%) memiliki tingkat kebugaran jasmani 2243-2623, sisanya 1 orang (5\%) memiliki tingkat kebugaran jasmani 2624-3004. Agar lebih jelasnya distribusi frekuensi tingkat kebugaran jasmani dapat dilihat pada gambar histogram 2.

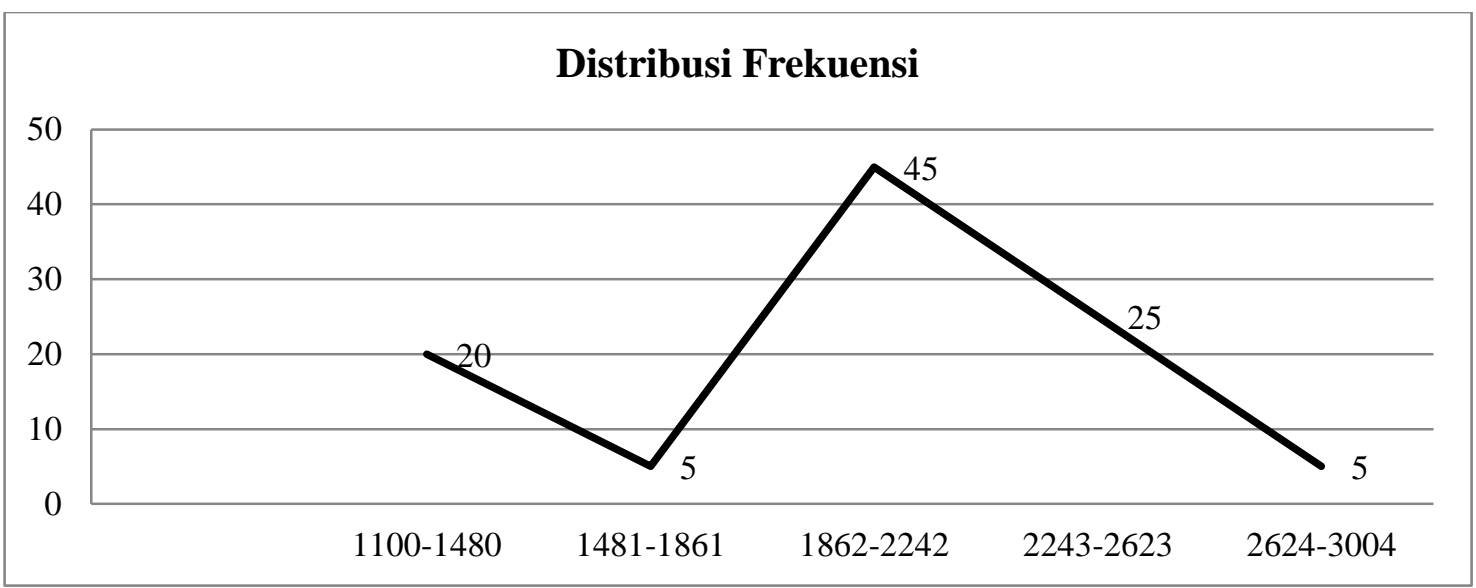

Gambar 2. Histogram Tingkat Kebugaran Jasmani

\section{Uji Persyaratan Analisis}

Sebelum melakukan pengujian hipotesis tentang kapasitas vital paru (x) dengan tingkat kebugaran jasmani (y) menggunakan person product momen, terlebih dahulu dilakukan uji normalitas data. Hasil analisis data masing-masing variabel disajikan tabel 3 .

Tabel 3. Rangkuman Uji Normalitas Sebaran Data dengan Uji Lilliefors

\begin{tabular}{clcccc}
\hline No & \multicolumn{1}{c}{ Variabel } & $\mathbf{N}$ & Lo & $\mathbf{L}_{\text {tabel }} \boldsymbol{\alpha}=\mathbf{0 . 0 5}$ & Distribusi \\
\hline 1 & Kapasitas vital paru (x) & 20 & 0.170 & 0.190 & Normal \\
\hline 2 & Tingkat kebugaran jasmani & 20 & 0.134 & 0.190 & Normal \\
\hline
\end{tabular}

Berdasarkan uraian di atas, maka dapat disimpulkan data berdistribusi normal, karena $\mathrm{L}_{\mathrm{o}}$ nya lebih kecil daripada $\mathrm{L}_{\text {tabel }}$ dengan $\alpha=0.05$. Data masing-masing variabel 
penelitian berasal dari data sampel yang berdistribusi normal serta dapat dilanjutkan dengan analisa person product moment.

\section{Uji Hipotesis}

Berdasarkan hasil pengukuran diperoleh analisis korelasi kapasitas vital paru (x) terhadap tingkat kebugaran jasmani (y) seperti tabel 4.

Tabel 4. Analisis Korelasi Kapasitas Vital Paru Terhadap Tingkat Kebugaran Jasmani

\begin{tabular}{cccc}
\hline DK (N-1) & $\mathbf{r}_{\text {hitung }}$ & $\mathbf{r}_{\text {tabel }} \boldsymbol{\alpha}=\mathbf{0 . 0 5}$ & Kesimpulan \\
\hline 19 & 0.622 & 0.456 & Terdapat hubungan yang signifikan \\
\hline
\end{tabular}

Berdasarkan tabel di atas diperoleh $r_{\text {hitung }}(0.622)$, sedangkan $r_{\text {tabel }}$ pada tingkat pegujian signifikan $\alpha=0.05$ adalah 0.456 . Hal ini memperlihatkan bahwa $r_{\text {hitung }}(0.622)$ $>r_{\text {tabel }}(0.456)$, sehingga bisa ditarik konklusi adanya interaksi yg signifikan antara kapasitas vital paru (x) terhadap tingkat kebugaran jasmani (y). Dengan $\alpha=0,05$ dan $\mathrm{dk}=\mathrm{n}-2$, diperoleh nilai $\mathrm{t}_{\text {tabel }}=1.734$, yaitu berdasarkan $1-\alpha$ atau $\alpha=0,05$ menjadi $\mathrm{dk}$ pembilang dan n-2 (18) menjadi dk penyebut. Kriteria pengujian adalah: jika $t_{\text {hitung }}>$ $\mathrm{t}_{\text {tabel}}$, Ho yg menyatakan nir terdapat hubungan antara variabel ditolak. Sebaliknya apabila $t_{\text {hitung }}<t_{\text {tabel }}>t_{\text {tabel }}(1.734)$ maka Ho ditolak, dan Ha diterima. Dengan demikian dapat disimpulkan bahwa terdapat interaksi yang signifikan antara variabel bebas dengan variabel terikat. Dengan istilah lain terdapat hubungan yang berarti antara antara kapasitas penting paru $(\mathrm{x})$ terhadap tingkat kebugaran jasmani (y).

Tabel 5. Analisis Korelasi Antara Antara Kapasitas Vital Paru Terhadap Tingkat Kebugaran Jasmani

\begin{tabular}{cccc}
\hline $\mathbf{N}-2$ & $\mathbf{t}_{\text {hitung }}$ & $\mathbf{t}_{\text {tabel }} \boldsymbol{\alpha}=\mathbf{0 . 0 5}$ & Kesimpulan \\
\hline 18 & 3,369 & 1.734 & Signifikan \\
\hline
\end{tabular}

Hasil analisis korelasi menyatakan terdapat hubungan yang signifikan antara antara kapasitas vital paru (x) terhadap tingkat kebugaran jasmani (y) pada taraf signifikan $\alpha=$ 0.05. Penelitian ini bertujuan untuk mengetahui korelasi kapasitas vital paru dengan tingkat kebugaran jasmani atlet sepakbola Pendor Universitas Riau. Berdasarkan data di atas, dapat diketahui bahwa kapasitas vital paru memiliki hubungan yang signifikan dengan tingkat kebugaran jasmani. Diperoleh $r_{\text {hitung }}(0.622)$, sedangkan $r_{\text {tabel }}$ adalah 0.456. Selanjutnya dalam uji signifikansi, diperoleh nilai $t_{\text {tabel }}=1.734$ dan $t_{\text {hitung }}=3.369$ yang artinya terdapat $t_{\text {hitung }}>t_{\text {tabel }}$.

Kapasitas vital paru merupakan jumlah udara yang dapat dikeluarkan (ekspirasi) paru sebanyak-banyaknya setelah menghirup udara (inspirasi) sedalam-dalamnya, jumlah tersebut berasal dari volume cadangan inspirasi, vital volume dan cadangan ekspirasi (Hakked et al., 2017). Kapasitas vital paru berguna untuk mengetahui kemampuan otot dan organ pernafasan dalam melakukan inspirasi dan ekspirasi (Hakked et al., 2017). Jika kemampuan otot dan organ pernafasan baik maka akan mampu memenuhi kebutuhan oksigen $\left(\mathrm{O}_{2}\right)$ dalam tubuh untuk melakukan aktifitas yang cukup lama.

Durmic et al., (2017) menyebutkan nilai dari pengukuran kapasitas vital paru (vital capasity) bermanfaat pada memberikan fakta mengenai kekuatan otot-otot pernafasan dan beberapa aspek fungsi pernafasan. Jadi hasil pengukuran akan menjelaskan besarnya kemampuan kapasitas vital paru dan mengungkapkan kemampuan fungsi paru 
untuk mengantarkan oksigen (O2) keseluruh otot \& sel guna membakar zat-zat makanan menjadi energi untuk melakukan aktifitas fisik yg dimaksudkan dalam penelitian ini adalah tingkat kebugaran jasmani (Durmic et al., 2017). Kemudian Milanović et al., (2019) menyatakan kebugaran jasmani adalah suatu kemampuan yang menitik beratkan dalam fungsi-fungsi fisiologis, yaitu kemampuan jantung, pembuluh darah, paru dan otot yang berfungsi dalam efisiensi yang optimal. Berdasarkan hasil penelitian diperoleh $r_{\text {hitung }}(0.622)>r_{\text {tabel }}(\alpha=0.05)$ yaitu 0.456 . Hal ini menerangkan bahwa terdapat interaksi yang berarti antara kapasitas penting paru (x) terhadap taraf kebugaran jasmani (y). Artinya dapat dikemukakan bahwa kapasitas penting paru memiliki interaksi yg berarti terhadap tingkat kebugaran jasmani. Artinya dalam penyediaan oksigen bagi tubuh bermanfaat untuk mengoksidasi nutrisi menjadi energi yg berguna bagi tubuh buat oksigen yg dapat ditampung oleh paru-paru akan memenuhi kebutuhan oksigen dalam sel organ pada saat bernafas.

Kapasitas vital paru merupakan jumlah udara yang dapat dikeluarkan paru sebanyak-banyaknya setelah menghirup udara sedalam-dalamnya. Jumlah tersebut berasal dari volume cadangan inspirasi, vital volume dan cadangan ekspirasi. Kapasitas vital paru berguna untuk mengetahui kemampuan otot dan organ pernafasan dalam melakukan inspirasi dan ekspirasi. Jika kemampuan otot dan organ pernafasan baik maka akan mampu memenuhi kebutuhan oksigen dalam tubuh untuk melakukan aktifitas yang cukup lama. Nilai dari pengukuran kapasitas vital paru (vital capasity) bermanfaat dalam memberikan informasi mengenai kekuatan otot-otot pernafasan serta beberapa aspek fungsi pernafasan (Durmic et al., 2017). Jadi hasil pengukuran akan menjelaskan besarnya kemampuan kapasitas vital paru dan menjelaskan kemampuan fungsi paru untuk mengantarkan oksigen $\left(\mathrm{O}_{2}\right)$ keseluruh otot dan sel guna membakar zat-zat makanan menjadi energi untuk melakukuan aktifitas fisik yang dimaksudkan dalam penelitian ini adalah tingkat kebugaran jasmani. Kemudian Coast et al., (2005) menyatakan kebugaran jasmani adalah suatu kemampuan yang menitik beratkan pada fungsi-fungsi fisiologis, yaitu kemampuan jantung, pembuluh darah, paru dan otot yang berfungsi pada efisiensi yang optimal.

Banyak sedikitnya volume udara tergantung dari baik buruknya kapasitas paru-paru kita, dan juga dipengaruhi oleh baik buruknya kualitas udara yang kita hirup. Kemampuan penggunaan oksigen oleh tubuh mempunyai kemampuan terbatas dalam pengambilan oksigen. Pada saat berolahraga, produksi karbondioksida akan bertambah seiring dengan itu kebutuhan $\mathrm{O}_{2}$ dalam sel-sel sangat tinggi. Pembuangan $\mathrm{CO}_{2}$ yang meningkat dilakukan oleh sistem pernapasan. Sehingga pada olahraga yang intensif, frekuensi pernapasan akan bertambah guna menghasilkan ventilasi paru yang besar. Semakin banyak frekuensi pernapasan maka semakin banyak pula udara yang tidak ikut menyegarkan alveoli. Kesimpulannya semakin tinggi frekuensi pernapasan itu kurang efisien. Rekomendasi kepada praktisi bidang olahraga untuk memperhatikan kualitas latihan yang sesuai untuk meningkatkan kualitas vital paru, karena ini penting untuk menentukan prestasi puncak yang kita inginkan.

\section{KESIMPULAN}

Hasil temuan penelitian ini menunjukkan bahwa kapasitas vital paru berhubungan erat dengan kebugaran jasmani dengan diperolehnya $r_{\text {hitung }}(0.622)>r_{\text {tabel }}$ yaitu 0.456 . Dapat kita membuktikan bahwa terdapat hubungan antara kapasitas vital paru terhadap tingkat kesegaran jasmani. Untuk uji signifikansi, diperoleh output $t_{\text {hitung }}(3,369)>t_{\text {tabel }}$ 
(1.734) artinya Ho ditolak, dan Ha diterima. Kesimpulannya terdapat hubungan yang signifikan antara kapasitas vital paru terhadap tingkat kebugaran jasmani.

\section{DAFTAR PUSTAKA}

Bennike, S., Wikman, J. M., \& Ottesen, L. S. (2014). Football Fitness - a new version of football? A concept for adult players in Danish football clubs. Scandinavian Journal of Medicine and Science in Sports, 24(1), 138-146. https://doi.org/10.1111/sms.12276

BenOunis, O., BenAbderrahman, A., Chamari, K., Ajmol, A., BenBrahim, M., Hammouda, A., ... Zouhal, H. (2013). Association of short-passing ability with athletic performances in youth soccer players. Asian Journal of Sports Medicine, 4(1), 41-48. https://doi.org/10.5812/asjsm.34529

Chu, C., Chen, F., Pontifex, M. B., \& Sun, Y. (2016). Health-related physical fitness, academic achievement, and neuroelectric measures in children and adolescents. International Journal of Sport and Exercise Psychology, 17(2), 1-16. https://doi.org/10.1080/1612197X.2016.1223420

Coast, J. R., Baronas, J. L., Morris, C., \& Willeford, K. S. (2005). The effect of football shoulder pads on pulmonary function. Journal of Sports Science and Medicine, $4(4), 367-371$.

Cvetković, N., Stojanović, E., Stojiljković, N., Nikolić, D., Scanlan, A. T., \& Milanović, Z. (2018). Exercise training in overweight and obese children: Recreational football and high-intensity interval training provide similar benefits to physical fitness. Scandinavian Journal of Medicine and Science in Sports, 28. https://doi.org/10.1111/sms.13241

Durmic, T., Lazovic, B., Djelic, M., Lazic, J. S., Zikic, D., Zugic, V., ... Mazic, S. (2015). Sport-specific influences on respiratory patterns in elite athletes. Jornal Brasileiro de Pneumologia, 41(6), 516-522. https://doi.org/10.1590/s180637562015000000050

Durmic, T., Popovic, B. L., Svenda, M. Z., Djelic, M., Zugic, V., Gavrilovic, T., ... Leischik, R. (2017). The training type influence on male elite athletes' ventilatory function. BMJ Open Sport and Exercise Medicine, 3(1). https://doi.org/10.1136/bmjsem-2017-000240

Gastin, P. B., Tangalos, C., Torres, L., \& Robertson, S. (2017). Match running performance and skill execution improves with age but not the number of disposals in young Australian footballers. Journal of Sports Sciences, 35(24). https://doi.org/10.1080/02640414.2016.1271137 
Hakked, C. S., Balakrishnan, R., \& Krishnamurthy, M. N. (2017). Yogic breathing practices improve lung functions of competitive young swimmers. Journal of Ayurveda and Integrative https://doi.org/10.1016/j.jaim.2016.12.005

Hammami, A., Randers, M. B., Kasmi, S., Razgallah, M., Tabka, Z., Chamari, K., \& Bouhlel, E. (2018). Effects of soccer training on health-related physical fitness measures in male adolescents. Journal of Sport and Health Science, 7(2). https://doi.org/10.1016/j.jshs.2017.10.009

Lardika, R. A., \& Tulyakul, S. (2020). The Effect of Direct Instruction Model in Physical Education Towards Students' Adversity Quotient (AQ). Journal Sport Area, 5(1), 1-12.

Mackenzie, B. (2005). 101 Performance Evaluation Tests. London: Electric World plc.

Milanović, Z., Pantelić, S., Čović, N., Sporiš, G., Mohr, M., \& Krustrup, P. (2019). Broad-spectrum physical fitness benefits of recreational football: a systematic review and meta-analysis. British Journal of Sports Medicine, 53(15). https://doi.org/10.1136/bjsports-2017-097885

Moore, V. C. (2012). Spirometry: step by step. Breathe, 8(3), 233-240.

Morita, N., Nakajima, T., Okita, K., Ishihara, T., Sagawa, M., \& Yamatsu, K. (2016). Relationships among fitness, obesity, screen time and academic achievement in Japanese adolescents. Physiology \& Behavior, 163, 161-166. https://doi.org/10.1016/j.physbeh.2016.04.055

Price, O. J., Hull, J. H., Ansley, L., Thomas, M., \& Eyles, C. (2016). Exercise-induced bronchoconstriction in athletes - A qualitative assessment of symptom perception. Respiratory Medicine, 120, 36-43. https://doi.org/10.1016/j.rmed.2016.09.017

Raine, L. B., Biggan, J. R., Baym, C. L., Saliba, B. J., Cohen, N. J., \& Hillman, C. H. (2017). Adolescent Changes in Aerobic Fitness are Related to Changes in Academic Achievement. Pediatric Exercise Science, 30(1), 106-114.

Smith, M. P., Berg, A. V., Berdel, D., Bauer, C. P., Hoffmann, B., Koletzko, S., ... Schulz, H. (2016). Physical activity is not associated with spirometric indices in lung-healthy German youth. European Respiratory Journal, 48(2). https://doi.org/10.1183/13993003.01408-2015

Sujarwo, Tangkudung, J., \& Hanif, A. S. (2018). The effect of vital capacity of the lungs, nutritional status, physical activity and exercise motivation towards physical fitness on the athlete package national sports committee Indonesia Depok City. JIPES Journal of Indonesian Physical Education and Sport, 4(2), 71-78. 
Tahara, Y., Moji, K., Tsunawake, N., Fukuda, R., Nakayama, M., Nakagaichi, M., ... Aoyagi, K. (2006). Physique, body composition and maximum oxygen consumption of selected soccer players of Kunimi High School, Nagasaki, Japan. Journal of Physiological Anthropology, 25(4). https://doi.org/10.2114/jpa2.25.291

Zainur, Z., \& Lardika, R. A. (2019). Effects of Kicking Nine Ball Training on Goals to Improve Shooting Accuracy Skills of Class IIIA Physical Education Students FKIP UNRI. In Proceedings of the UR International Conference on Educational Sciences (pp. 70-75). Pekanbaru. 